\title{
Functional capacity and quality of life in older women practicing and not practicing hydrogymnastics
}

\author{
Capacidade funcional e qualidade de vida em mulheres idosas praticantes e não praticantes \\ de hidroginástica
}

Daniel Vicentini de Oliveira ${ }^{1}$, José Roberto Andrade do Nascimento Júnior ${ }^{2}$, Maria do Carmo Correia de Lima ${ }^{1}$, Daniel Eduardo da Cunha Leme ${ }^{1}$, Mateus Dias Antunes ${ }^{3}$, Sônia Maria Marques Gomes Bertolini ${ }^{3}$

\begin{abstract}
Objective: to compare the functional capacity and quality of life of older women practicing and not practicing hydrogymnastics. Methods: this is a simple natural experiment study, of a sample of 40 older women practicing hydrogymnastics and 40 not practicing hydrogymnastics. Latin American Development Group's protocol was used to evaluate the functional capacity, and the WHOQOL-Bref and Old was used to evaluate the quality of life. Results: there were no differences in functional capacity or quality of life between the groups. Conclusion: it is concluded that there was not enough strong evidence to prove that older women practicing hydrogymnastics have a different functional capacity and quality of life compared to those not practicing physical exercise.
\end{abstract}

Descriptors: Aging; Exercise; Geriatrics; Health Promotion.

Objetivo: comparar a capacidade funcional e a qualidade de vida de mulheres idosas que praticam e que não praticam hidroginástica. Métodos: trata-se de um experimento simples natural, de uma amostra de 40 mulheres idosas praticantes de hidroginástica e 40 não praticantes. 0 protocolo do Grupo de Desenvolvimento LatinoAmericano foi utilizado para avaliar a capacidade funcional e o WHOQOL-Bref e o WHOQOL-Old para avaliar a qualidade de vida. Resultados: não houve diferenças na capacidade funcional ou qualidade de vida entre os grupos. Conclusão: conclui-se que não houve evidência suficiente para provar que mulheres idosas praticantes de hidroginástica têm capacidade funcional e qualidade de vida diferentes em comparação com aquelas que não praticam exercício físico.

Descritores: Envelhecimento; Exercício; Geriatia; Promoção da Saúde.

\footnotetext{
${ }^{1}$ Universidade Estadual de Campinas. Campinas, SP, Brazil.

${ }^{2}$ Universidade Federal do Vale do São Francisco. Petrolina, PE, Brazil.

${ }^{3}$ Centro Universitário de Maringá. Maringá, PR, Brazil.
} 


\section{Introduction}

Aging is a dynamic, progressive and heterogeneous process with morphological, biochemical, psychological and functional changes such as a decrease in motor skills, loss of strength, flexibility, and movement. These modifications hinder the ability to perform daily physical activities, leading to loss of an older person's ability to adapt to the environment, causing greater vulnerability and a higher incidence of sickness process, and may cause difficulties for the older adult over time, especially regarding functional capacity ${ }^{(1)}$.

Public policies and actions for the older population with a longer life expectancy should be maintained and enhanced to ensure not only better health condition, but also the quality of life for the older adult. The World Health Organization proposes an active aging policy for optimizing opportunities for health, participation, and security to improve the quality of life of the older individual ${ }^{(2)}$.

The quality of life in old age is a multidimensional construct related to health, physical and cognitive functionality, activity, productivity, and capacity for emotional regulation, as well as subjective and economic well-being, and ecological and social resources consistent with the needs of an older adult. It is important to invest in the search for a better quality of life through healthy habits such as physical exercise to mitigate a major cause of morbidity and mortality in this age $\operatorname{group}^{(3)}$.

Among the existing exercise modalities, hydrogymnastics stands out for being a safe environment and not only providing physical benefits, but also emotional and social benefits among older adults. The literature suggests that activity in the water allows a person physical, mental and psychological expan$\operatorname{sion}^{(4)}$.

Specific aquatic exercises have the advantage of causing less impact on the lower limbs, based on the improvement of water resistance as overload and thrust as a redactor of the impact with decreased risk of injury, facilitating practice for those people who cannot afford their own weight when performing a ground exercise because when the body immerses, the water is displaced and creates a fluctuation force that removes the burden of immersed joints. Thus, hydrogymnastics is one of the main recommendations for older adult patients with alterations ${ }^{(5)}$.

Improvement of the components of aerobic conditioning, muscle strength, muscular endurance, flexibility and body composition are also benefits of hydrogymnastics, mainly due to the physical properties of water that provide support for less impact on the joints, relaxation, balance, decreased body weight, increased resistance to movement, improved cardio-respiratory system, improve physical fitness and mental well-being ${ }^{(5)}$.

These features and benefits of hydrogymnastics highlight the modality among the exercise possibilities for older adults. Therefore, it enables the work of large muscle groups at the same time, combining aerobic exercise without risk of falls ${ }^{(6)}$. Conducted in groups, it becomes easy socializing, enjoying the music as increment for motivation. With this assumption, this study aimed to compare the functional capacity and quality of life of older women when practicing and not practicing hydrogymnastics.

\section{Methods}

The sample consisted of 80 older women (6070 years of age), 40 of whom were practicing hydrogymnastics (63.0 \pm 3.1 years old), for at least three months at a frequency of twice a week, and 40 of whom were not practicing physical exercise (65.60 \pm 3.7 years old). Older women with neurological disorders were excluded (showing motor or psychological signs and symptoms), as limited by their performance on tests and questionnaires. The exclusion of the stu- 
dy of male participants and adults older than 70 years is justified by the fact that most older males and adults older than 70 years old were not practicing hydrogymnastics during the study period.

Older women practicing hydrogymnastics were randomly selected from the eight fitness centers that offered this exercise modality in 2013. A process of simple randomization was applied among the practitioners. Older adults not practicing exercises were selected from five domiciles by convenience.

A semi-structured sample characterization form was used composed of information regarding age (years), marital status (married or not married), employment status (active or inactive), monthly income in minimum wages as referenced from the 2012 Demographic Population Census of the Brazilian Institute of Geography and Statistics (1 to 2 minimum salaries and more than 2).

Functional capacity was assessed using the Functional Assessment Protocol tests of the Maturity Latin American Development Group (GDLAM): walking 10 meters, standing up in a sitting position, standing up in the prone position, standing up from a chair and moving around the house, and putting on and taking off a shirt ${ }^{(7)}$.

All tests were used to calculate the $\operatorname{GDLAM}^{(7)}$, index and the times were calculated in seconds. The smaller the scores obtained, the higher the level of functional capacity. GDLAM was calculated as follows:

GDLAM $=[$ (walking 10 meters + standing up in a sitting position + standing up in the prone position + putting on and taking off a shirt $\mathrm{x} 2]+$ standing up from a chair and moving around the house

\section{4}

Quality of life was evaluated by the World Health Organization Quality of Life (WHOQOL-Bref), which consists of 26 questions divided into four domains, ranging from 4-20 for each domain, and 20-100 for the overall quality of life, and also WHQOOL-Old, which is composed of 24 questions divided into five fa- cets, ranging from 4-20 each facet and 0-100 for the overall quality of life $\mathrm{e}^{(8)}$.

Data collection was performed between the months of May to August 2013. Direct interviews were chosen for implementing these instruments, given the participants' possibly having difficulty in reading, visual problems and understanding the questions.

Frequency and percentage for categorical variables were used for data analysis. The Kolmogorov-Smirnov test was initially used to verify data normality for numeric variables. As the data did not show normal distribution, Median (Md) and Quartiles (Q1; Q3) were used for characterizing the results. The Mann-Whitney "U" test was used for comparing the groups (practicing and not practicing hydrogymnastics). The Spearman correlation test was used to verify the correlation between the variables (functional capacity and quality of life), and a significance of $p<0.05$ was adopted for all tests. All analyses were performed using Statistical Package for Social Sciences software version 22.0.

The study complied with the formal requirements contained in the national and international standards of regulatory research involving human subjects.

\section{Results}

It should be noted that both groups were homogenous regarding marital status and occupational status $(\mathrm{p}<0.05)$. However, a significant association was found $(\mathrm{p}=0.022)$ between the two groups and monthly income, showing a higher proportion of women who practice hydrogymnastics with a monthly income above two minimum wages ( $\mathrm{f}=72.5 \%$ ).

Table 1 shows the comparison of tests related to the functional ability of older women practicing and not practicing hydrogymnastics. Regarding general functional capacity (GDLAM), no differences were found between the groups ( $p=0.397)$. 
Table 1 - Comparison of tests related to the functional capacity of older women practicing or not practicing hydrogymnastics. $(\mathrm{n}=40)$

\begin{tabular}{|c|c|c|c|}
\hline GDLAM tests & $\begin{array}{l}\text { Hydrogymnastics } \\
\text { practitioners }\end{array}$ & Non-practitioners & p \\
\hline & Median (Q1; Q3) & Median (Q1; Q3) & \\
\hline Walking 10 meters ${ }^{a}$ & $10.00(8.55 ; 12.10)$ & $10.70(9.00 ; 13.00)$ & 0.433 \\
\hline $\begin{array}{l}\text { Standing up in a sitting } \\
\text { position }^{\text {a }}\end{array}$ & $10.00(7.00 ; 12.50)$ & $12.67(9.66 ; 15.90)$ & $0.010^{*}$ \\
\hline $\begin{array}{l}\text { Standing up in the prone } \\
\text { position }^{\text {a }}\end{array}$ & $9.05(6.95 ; 11.00)$ & $7.55(5.00 ; 9.85)$ & $0.044^{*}$ \\
\hline $\begin{array}{l}\text { Standing up from a chair and } \\
\text { moving around the house }\end{array}$ & $48.50(39.00 ; 51.07)$ & $45.45(40.41 ; 53.62)$ & 0.885 \\
\hline $\begin{array}{l}\text { Putting on and taking off a } \\
\text { shirt }^{a}\end{array}$ & $9.04(7.00 ; 10.15)$ & $8.90(6.80 ; 11.75)$ & 0.935 \\
\hline GDLAM $^{\mathrm{b}}$ & $31.79(27.75 ; 34.66)$ & $31.75(29.22 ; 36.34)$ & 0.397 \\
\hline
\end{tabular}

There was a significant difference (Table 1 ), in the Standing up in a sitting position test $(\mathrm{p}=0.010)$ and Standing up in the prone position $(\mathrm{p}=0.044)$. It is noted that the older woman practicing hydrogymnastics showed better results in SUPP test, while the elderly women who were not practicing hydrogymnastics showed superior results in the Standing up in a sitting position test.

Table 2 - Comparison of quality of life of WHOQOL-Bref for older women practicing or not practicing hydrogymnastics. $(n=40)$

\begin{tabular}{|c|c|c|c|}
\hline \multirow{2}{*}{$\begin{array}{l}\text { WHOQOL-Bref quality } \\
\text { of life domains }\end{array}$} & $\begin{array}{l}\text { Hydrogymnastics } \\
\text { practitioners }\end{array}$ & Non-practitioners & \multirow{2}{*}{$\mathbf{p}$} \\
\hline & Median (Q1; Q3) & Median (Q1; Q3) & \\
\hline 1 - Physical & $14.28(12.00 ; 15.43)$ & $15.43(13.71 ; 16.57)$ & $0.036^{*}$ \\
\hline 2 - Psychological & $16.00(14.67 ; 16.67)$ & $15.33(14.67 ; 16.67)$ & 0.588 \\
\hline 3 - Social & $14.67(14.67 ; 16.00)$ & $14.67(13.33 ; 16.00)$ & 0.321 \\
\hline 4 - Environment & $14.50(12.00 ; 15.50)$ & $14.50(12.00 ; 15.50)$ & 0.678 \\
\hline 5 - Self-evaluation & $16.00(14.00 ; 16.00)$ & $16.00(12.50 ; 17.50)$ & 0.800 \\
\hline Total Quality of life & $76.14(68.00 ; 81.23)$ & $75.36(69.84 ; 78.90)$ & 0.733 \\
\hline
\end{tabular}

As for the quality of life assessed by WHOQOL-Bref (Table 2), a significant difference was found between the groups in the physical domain $(\mathrm{p}=0.036)$, indicating that older women not practicing hydrogymnastics (Median=15.43) had a higher perception of quality of life-related to the physical aspects compared to older women practicing hydrogymnastics (Median=14.28).

When comparing the quality of life aspects of WHOQOL-Old among the older women practicing and not practicing hydrogymnastics (Table 3), it was observed that elderly women not practicing (Median=17.00) had a higher perception of quality of life in their senses working $(\mathrm{p}=0.007)$ over the older women practicing hydrogymnastics (Median=15.00).

Table 3 - Comparison of Whoqol-Old quality of life facets for, older women practicing or not practicing hydrogymnastics. $(\mathrm{n}=40)$

\begin{tabular}{|c|c|c|c|}
\hline WHOQOL-Old quality & $\begin{array}{l}\text { Hydrogymnastics } \\
\text { practitioners }\end{array}$ & Non-practitioners & $\mathbf{p}$ \\
\hline & Median (Q1; Q3) & Median (Q1; Q3) & \\
\hline Functioning senses & $15.00(13.00 ; 16.00)$ & $17.00(15.00 ; 17.00)$ & $0.007^{*}$ \\
\hline Autonomy & $15.00(14.00 ; 17.00)$ & $15.00(12.00 ; 15.00)$ & 0.229 \\
\hline $\begin{array}{l}\text { Past, present and future } \\
\text { activities }\end{array}$ & $16.00(15.00 ; 17.00)$ & $15.00(13.00 ; 16.00)$ & $0.022^{*}$ \\
\hline Personal participation & $15.00(13.00 ; 17.00)$ & $13.00(11.00 ; 16.75)$ & $0.016^{*}$ \\
\hline Death and dying & $15.00(10.00 ; 18.00)$ & $14.50(12.00 ; 18.00)$ & 0.602 \\
\hline Intimacy & $16.00(16.00 ; 19.00)$ & $15.50(13.00 ; 17.00)$ & $0.005^{*}$ \\
\hline Total quality of life & $93.00(81.00 ; 100.00)$ & $88.50(79.00 ; 94.00)$ & 0.216 \\
\hline
\end{tabular}

Significant differences in the past, present and future activities $(\mathrm{p}=0.022)$, personal involvement $(\mathrm{p}=0.016)$ and intimacy $(\mathrm{p}=0.005)$ were also found, showing that older woman practicing hydrogymnastics have a better perception of quality of life in these facets compared to older women not practicing hydrogymnastics. 


\section{Discussion}

When assessing the functional capacity of the older women, there was no difference between groups; more specifically, older women who practice hydrogymnastics have the same functional capacity of older women who do not practice physical exercise. However, when evaluating the sample by the GDLAM tests, older women not practicing physical exercises got better results on the Standing up in a sitting position tests compared to older women practicing hydrogymnastics. This fact can apparently be justified because of what is experienced in practice; older women usually seek the hydrogymnastics modality when they have functional limitations in their knees, pain, decreased range in their knee joints, or the presence of rheumatic diseases such as osteoarthritis and osteoporosis as it promotes low impact on the hip, knee and ankle joints resulting from the physical properties of water, which reduces body weight by $90.0 \%{ }^{(9)}$.

These individuals commonly have multiple chronic disorders, which generate aches and pains, and/or difficulty in daily activities such as standing up from a chair. It is known that the presence of pain and discomfort is closely associated with decreased muscle strength and functionality ${ }^{(10)}$.

It is noteworthy that the Standing up in a sitting position test aims to assess the functional capacity of the lower extremities and consists of the individual performing the following procedure: starting from a sitting position in a chair without an armrest with the seat at a distance of $50 \mathrm{~cm}$ from the ground, then standing up and sitting down five times consecutively ${ }^{(7)}$. In this context, older women practicing hydrogymnastics had better results in functional capacity on the Standing up in the prone position test compared to older women not practicing physical exercise.

The act of standing up from the floor stimulates and uses a larger amount of joints, and not just one (like the knee in the Standing up in a sitting position act), and during a hydrogymnastics class, water hei- ght remains at the height of the sternum xiphoid process, so that the majority of body joints are immersed and have to overcome water resistance during movement ${ }^{(4)}$. This fact may explain the better functional performance of older women practicing hydrogymnastics on that test.

In hydrogymnastics, the exercises producing a greater resistance in the water can be used for increasing the execution speed or by changing the projected area which can be modified by using the body in different ways in the water and also by executing exercises using the resistance ${ }^{(9)}$.

Regarding the other tests (Walking 10 meters, Putting on and taking off a shirt, Standing up from a chair and moving around the house), no differences were found between the groups, which can be justified by the fact that when the intervention was performed, it did not produce an effect compatible with clear benefits on the functionality of the subjects.

Interestingly, the perception of quality of life-related to the physical domain of the WHOQOL-Bref was higher in the group of older women not practicing hydrogymnastics (15.43), but similar to the older group practicing hydrogymnastics (14.28) during a minimum period of three months and at a frequency of twice a week.

The fact that older women practicing hydrogymnastics are occupationally more active $(\mathrm{p}=0.07)$ (statistical trend) could have influenced this result. Maybe older people who work have a perception of better quality of life.

As already noted, generally older adults adhere to hydrogymnastics due to the low impact on joints, and they already have muscle and/or chronic joint disorders. This clinical profile may have negatively influenced the scores of issues relating to the physical domain of the WHOQOL-Bref in the present study. Furthermore, the literature points out that disability due to chronic morbidities of the musculoskeletal system can influence a decrease in score on the physical domain in evaluating the quality of life ${ }^{11}$. 
Still, basing the findings of this study in other research verified that as the number of physical disabilities increase, the score was reduced in the physical domain of evaluating the quality of life. In a study ${ }^{(12)}$ showed that older people with physical disabilities were 36.1 times more likely to have a worse quality of life in the physical domain than those without disabilities.

The WHOQOL-Bref has seven questions that evaluate the physical domain of quality of life: pain and discomfort; energy and fatigue; sleep and rest; mobility; activities of daily living; dependence on medication or treatment and capacity for work ${ }^{(9)}$. Different from our results, in a study ${ }^{(9)}$ noted that the quality of life-related to the physical domain in older women (6080 years) practicing hydrogymnastics over six months was better compared to older sedentary women of the same age group. The authors concluded that a regular and oriented hydrogymnastics program could bring physical health benefits for older adults, improving all aspects or at least part of that domain. A study ${ }^{(13)}$ with older women practicing hydrogymnastics in the city of Sarandi/Paraná found a quality of life score in the physical domain (15.0) similar to this research.

Regarding the perception of quality of life assessed by WHOQOL-Old, the older women not practicing hydrogymnastics scored better on "sense functioning," regarding older women practicing hydrogymnastics. Concerning WHOQOL-Bref, the WHOQOL-Old is an assessment tool for quality of life of the older adult. This result does not support the research which compared the perception of quality of life and physical fitness level of older adults practicing hydrogymnastics (hydrogymnastics and swimming), and noted that the practitioners of this exercise modality had better perceived quality in the "sensory abilities" facet of WHOQOL-old, even with poor flexibility levels of the upper limbs ${ }^{(14)}$.

In the "past, present and future activities," "social participation" and "intimacy," the scores were higher among the group practicing hydrogymnastics. It is known that physical exercise provides health benefits, improving the quality of life ${ }^{(15)}$ and promoting greater social participation and interaction among the older population ${ }^{(14)}$. In exercises focused on older people, fitness centers are a meeting point helping prevent depression and stress and improve sociability among these individuals. Such attributes probably positively influence the perception of levels of quality of life as assessed by WHOQOL-old among the above facets $^{(8)}$.

Regarding monthly income, there was a significant difference between the older women practicing and not practicing hydrogymnastics. Most older adult women practicing hydrogymnastics (72.5\%) had monthly income above two minimum wages. This result corroborates previous research performed in Brazil ${ }^{(16)}$ in which older adults ( $\geq 65$ years) with higher socioeconomic levels showed greater adherence to physical exercise regarding older adults of the same age and lower socioeconomic levels. Among the older adult population, clinical (comorbidities, functional disability, and depression) ${ }^{(17)}$ and socio-demographic factors (lower levels of education and monthly income) are associated with poor adherence to physical exercise ${ }^{(18)}$. It is noteworthy that hydrogymnastic practice requires a monthly cost, and consequently, there is a higher demand among individuals with higher monthly incomes. However, there is no consensus on it, and some studies ${ }^{(17-19)}$ show an inverse association between socioeconomic status and physical exercise practice in the older adult population.

The results show the need to verify the quality of hydrogymnastics classes that are being taught to older women, especially those with physical and functional disabilities. Despite evidence, there were better results in some quality of life facets (according to the WHOQOL-Old) for the older women practicing hydrogymnastics, yet having a worse perception of quality of life in the physical domain and worse performance in the Standing up in a sitting position functional 
test compared to the older adults who did not practice physical exercise; a result which was not expected.

The literature has evidenced that functional capacity level can be improved or maintained by performing some physical exercises, or at least its decline rate can be minimized. Inclusion in a regular exercise program can be a kind of effective intervention to reduce or even prevent the number of functional declines associated with aging ${ }^{(11)}$; however, this was not found in this study.

Despite the contributions of the findings of this study to the literature, some limitations need to be addressed. First, this research did not present statistical analyses about health conditions of older adults who do not practice physical exercise. Another limitation is related to the lack of volume and intensity parameters of water aerobics practice. Thus, future studies should explore these limitations, given that greater results in the above group would justify actions that encourage practicing of hydrogymnastics by the older adult population.

\section{Conclusion}

It is concluded that there was not strong enough evidence to prove that older women practicing hydrogymnastics have a different functional capacity to those not practicing physical exercise. In general, the perception of quality of life also had no difference between the groups.

\section{Collaborations}

Oliveira DV, Nascimento Júnior JRA, Lima MCC, Leme DEC contributed to the design, the collection of field data analysis, data interpretation and writing of the article. Antunes MD and Bertolini SMMG contributed to the design and final approval of the version to be published.

\section{References}

1. Cordeiro J, Castillo CLD, Freitas CS, Gonçalves MP. Efeitos da atividade física na memória declarativa, capacidade funcional e qualidade de vida em idosos. Rev Bras Geriatr Gerontol. 2014; 17(3):541-52.

2. Souto SVD, Novaes JS, Monteiro MD, Rodrigues Neto G, Carvalhal MIM, Coelho E. Body image in adult vs. middle-aged and elderly women practitioners and non-practitioners of hydro gymnastics. Motricidade. 2016; 12(1):53-9.

3. Ochoa-Martínez PY, Hall-Lopez JA, Ávila FAP, Rocha CAQC, Moreira MHR, Dantas EHM. Effect of three months of periodized hydrogymnastics exercise program on urinary concentration of deoxypyridinoline in older women. Arch Endocrinol Metab. 2015; 59(6):523-7.

4. Assunção AA, Carlos J, Souza RDP, Paz GA, Maia MDF, Lima VP. Comparação os níveis de flexibilidade entre idosas praticantes de ginástica localizada e hidroginástica. Rev Atenç Saúde, 2016; 14(47):19-24.

5. Garcia JS, Ciappina PC, Pereira ECA, Teodoro ECM, Pereira WMP. Avaliação da autonomia funcional do idoso ativo. Rev Ciênc Saúde. 2016; 1(1):51-60.

6. Jeronimo DP, Souza FP, Silva LR, Teodoro PHS. Avaliação da autonomia funcional de idosas fisicamente ativas e sedentárias. Rev Bras Ciênc Envelhec Hum. 2012; 8(2):173-8.

7. Snell DL, Siegert RJ, Surgenor LJ, Dunn JA, Hooper GJ. Evaluating quality of life outcomes following joint replacement: psychometric evaluation of a short form of the WHOQOL-Bref. Quali Life Res. 2016; 25(1):51-61.

8. Oliveira DV, Araújo APS, Bertolini SMMG. Cognitive and functional ability of elderly women practitioners of different modalities of exercise. Rev Rene. 2015; 16(6):872-80.

9. Bêta FCO, Dias IBF, Brown AF, Araújo CO, Simão RF. Comparação dos efeitos do treinamento resistido e da hidroginástica na autonomia de indivíduos idosos. Rev Bras Presc Fisiol Exerc. 2016; 10(58):220-4. 
10. Skou ST, Wise BL, Lewis CE, Felson D, Nevitt $M$, Segal NA, et al. Muscle strength, physical performance and physical activity as predictors of future knee replacement: a prospective cohort study. Osteoarthr Cartilag. 2016; 24(8):1350-56.

11. Moreira PL, Correa CR, Corrente JE, Martin LC, Boas PJFV, Ferreira ALA. Anthropometric, functional capacity, and oxidative stress changes in Brazilian community-living elderly subjects: a longitudinal study. Arch Gerontol Geriatr [Internet]. 2016 [cited 2016 Sept 13]; 66:140-6. Available from: http://www.aggjournal.com/article/S01674943(16)30099-1/pdf

12. Tomicki C, Zanini SCC, Cecchin L, Benedetti TRB, Portella MR, Leguisamo CP. Effect of physical exercise program on the balance and risk of falls of institutionalized elderly persons: a randomized clinical trial. Rev Bras Geriatr Gerontol. 2016; 19(3):473-82.

13. Silva RS, Nascimento Júnior JR, Vieira LF, Oliveira DV. Qualidade de vida e capacidade funcional de idosas praticantes de hidroginástica no município de Sarandi/PR. Rev Bras Qual Vida. 2016; 8(1):2841.

14. Gonçalves KC, Streir IA, Medeiros PA, Santos PM, Mazo GZ. Comparação entre a percepção da qualidade de vida e o nível de aptidão física de idosos praticantes de atividades aquáticas. Rev Aten Saúde. 2014; 12(39):35-40.
15. Castro DC, Nunes DP, Pagotto V, Pereira LV, Bachion MM, Nakatani AYK. Functional disability for basic activities of daily lives of the elderly: a population study. Cienc Cuid Saude. 2016; 15(1):109-17.

16. Mendonça RMSC, Araújo Júnior AT, Sousa C, Socorro M, Fernandes HM. The effects of different exercise programmes on female body composition. J Hum Kinetic. 2014; 43(1):67-78.

17. Loiola NNLA, Vieira DJN, Silva GMP. Caracterização de idosos participantes de atividade física em um centro de convivência de Teresina-PI. Enferm Foco. 2012; 3(1):7-11.

18. Campos ACV, Almeida MHM, Campos GV, Bogutchi TF. Prevalence of functional incapacity by gender in elderly people in Brazil: a systematic review with meta-analysis. Rev Bras Geriatr Gerontol. 2016; 19(3):545-59.

19. Hall-Lópes J, Ochoa-Martínes P, Teixeira AM, Moncada-Jiménez JÁ, Dantas EM. Efecto del ejercicio físico de hidrogimnasia sobre la concentración sérica de inmunoglobulina A en mujeres adultas mayores. Rev Chi Infectol. 2015; 32(3):272-7. 